University of Wollongong

Research Online

Faculty of Law, Humanities and the Arts Papers (Archive)

Faculty of Arts, Social Sciences \& Humanities

$1-1-2014$

Disability, abnormality and criminal law: sterilisation as lawful and 'good' violence

Linda Roslyn Steele

University of Wollongong, Isteele@uow.edu.au

Follow this and additional works at: https://ro.uow.edu.au/lhapapers

Part of the Arts and Humanities Commons, and the Law Commons

Research Online is the open access institutional repository for the University of Wollongong. For further information contact the UOW Library: research-pubs@uow.edu.au 


\title{
Disability, abnormality and criminal law: sterilisation as lawful and 'good' violence
}

\begin{abstract}
This article analyses the place of the intersections of the criminal law of assault and the Family Court's welfare jurisdiction in rendering Family Court authorised sterilisation of girls with intellectual disability a legally permissible form of violence. The article does this by examining court authorised sterilisation of girls with intellectual disability by reference to the concepts of 'legal violence' and 'abnormality'. The article's central argument is that Family Court authorised sterilisation of girls with intellectual disability is a form of lawful and 'good' violence against abnormal legal subjects. Such girls are - by reason of their incapacity - positioned outside the group of 'normal' legal subjects of assault who have the capacity to decide to consent to contact with their otherwise 'impermeable' and legally sacrosanct bodies. As the girls with intellectual disability are deemed to constitute 'abnormal' legal subjects of assault, the lawfulness of the contact involved in the act of their sterilisation is not dependent on the consent of the girls themselves, but instead on the consent of their parents as authorised by the Family Court acting in its welfare jurisdiction. In the course of authorising parental consent to sterilisation, the Family Court not only renders an act of sterilisation 'lawful violence', but also 'good violence' through the characterisation of girls with intellectual disability as absolutely different to individuals without disability, and through the characterisation of the act in legal, familial and medical terms.
\end{abstract}

\section{Disciplines}

Arts and Humanities | Law

\section{Publication Details}

L. Steele, 'Disability, abnormality and criminal law: sterilisation as lawful and 'good' violence' (2014) 23 (3) Griffith Law Review 467-497. 
This article was downloaded by: [University of Wollongong]

On: 16 March 2015, At: 15:37

Publisher: Routledge

Informa Ltd Registered in England and Wales Registered Number: 1072954 Registered

office: Mortimer House, 37-41 Mortimer Street, London W1T 3J H, UK

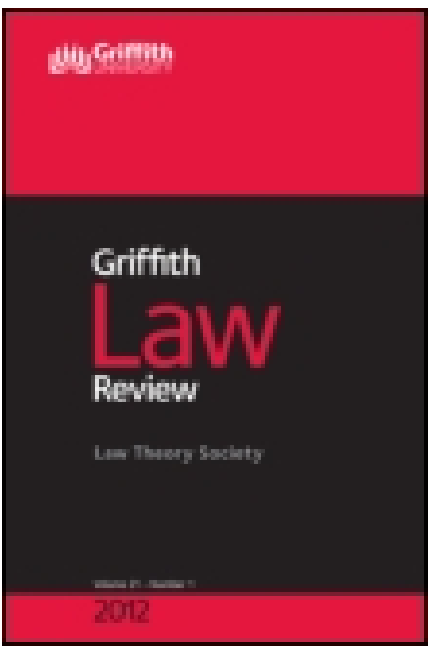

\title{
Griffith Law Review
}

Publication details, including instructions for authors and

subscription information:

http:// www.tandfonline.com/loi/ rlaw20

\section{Disability, abnormality and criminal law: sterilisation as lawful and 'good' violence}

\author{
Linda Steele ${ }^{a}$ \\ a School of Law, University of Wollongong, Wollongong, Australia \\ Published online: 20 Feb 2015.
}

\section{CrossMark}

Click for updates

To cite this article: Linda Steele (2014) Disability, abnormality and criminal law: sterilisation as lawful and 'good' violence, Griffith Law Review, 23:3, 467-497, DOI: 10.1080/ 10383441.2014.1000223

To link to this article: http:/ / dx. doi.org/ 10.1080/ 10383441.2014.1000223

\section{PLEASE SCROLL DOWN FOR ARTICLE}

Taylor \& Francis makes every effort to ensure the accuracy of all the information (the "Content") contained in the publications on our platform. However, Taylor \& Francis, our agents, and our licensors make no representations or warranties whatsoever as to the accuracy, completeness, or suitability for any purpose of the Content. Any opinions and views expressed in this publication are the opinions and views of the authors, and are not the views of or endorsed by Taylor \& Francis. The accuracy of the Content should not be relied upon and should be independently verified with primary sources of information. Taylor and Francis shall not be liable for any losses, actions, claims, proceedings, demands, costs, expenses, damages, and other liabilities whatsoever or howsoever caused arising directly or indirectly in connection with, in relation to or arising out of the use of the Content.

This article may be used for research, teaching, and private study purposes. Any substantial or systematic reproduction, redistribution, reselling, loan, sub-licensing, systematic supply, or distribution in any form to anyone is expressly forbidden. Terms \& 
Conditions of access and use can be found at http://www.tandfonline.com/page/termsand-conditions 


\title{
Disability, abnormality and criminal law: sterilisation as lawful and 'good' violence
}

\author{
Linda Steele* \\ School of Law, University of Wollongong, Wollongong, Australia
}

\begin{abstract}
This article analyses the place of the intersections of the criminal law of assault and the Family Court's welfare jurisdiction in rendering Family Court authorised sterilisation of girls with intellectual disability a legally permissible form of violence. The article does this by examining court authorised sterilisation of girls with intellectual disability by reference to the concepts of 'legal violence' and 'abnormality'. The article's central argument is that Family Court authorised sterilisation of girls with intellectual disability is a form of lawful and 'good' violence against abnormal legal subjects. Such girls are - by reason of their incapacity - positioned outside the group of 'normal' legal subjects of assault who have the capacity to decide to consent to contact with their otherwise 'impermeable' and legally sacrosanct bodies. As the girls with intellectual disability are deemed to constitute 'abnormal' legal subjects of assault, the lawfulness of the contact involved in the act of their sterilisation is not dependent on the consent of the girls themselves, but instead on the consent of their parents as authorised by the Family Court acting in its welfare jurisdiction. In the course of authorising parental consent to sterilisation, the Family Court not only renders an act of sterilisation 'lawful violence', but also 'good violence' through the characterisation of girls with intellectual disability as absolutely different to individuals without disability, and through the characterisation of the act in legal, familial and medical terms.
\end{abstract}

\section{Introduction}

Violence against women and girls with disability is a significant problem at a national and an international level. ${ }^{1}$ Sterilisation is recognised as a particular form of violence against women and girls with disability. ${ }^{2}$ Australian disability rights advocates have argued that sterilisation is a form of violence which should be prohibited

\footnotetext{
*Email: 1steele@uow.edu.au

${ }^{1}$ See, for example, Goodley and Runswick-Cole (2011); Hughes et al (2012); Dowse et al (2013); Roulstone and Mason-Bish (2013); see also Olle (2006) on the role of violence in causing disability in women and girls.

${ }^{2}$ See, for example, Women With Disability Australia et al (2011); Australian Human Rights Commission (2012); Broderick (2012); Méndez (2013) at [48] (citing A/64/272 at [55]). It is acknowledged that men and boys with disability are also subjected to sterilisation. However, research has established both empirically and discursively significant gendered dimensions of sterilisation such that it is appropriate to restrict the analysis in this article to the sterilisation of females. On the sterilisation of males with disability, see Keywood (2001, 2002); Savell (2004). For a historical discussion in the US context, see Jarman (2012).
} 
by criminal law $^{3}$ and these arguments have been echoed on an international level by a variety of United Nations human rights bodies. ${ }^{4}$

Yet the act of sterilisation has not been explicitly prohibited by criminal law in any Australian jurisdiction. To the contrary, the interplay of criminal law with family law and guardianship law means that sterilisation is legally permitted. Generally, pursuant to the criminal law of assault ('law of assault'), it is unlawful for an individual to make unwanted contact with another. ${ }^{5}$ Such contact constitutes the offence of common assault. Where the assault results in particular degrees of bodily harm, is committed by or to an individual belonging to particular categories or is committed in the context of particular situations, then this conduct is viewed as more reprehensible and constitutes a more serious (aggravated) assault offence. ${ }^{6}$ Sterilisation, which involves the removal or damaging of body organs, when done without the consent of the individual, prima facie constitutes aggravated assault. This is on the basis that the harm caused by sterilisation constitutes 'grievous bodily harm'. Grievous bodily harm is defined in the common law as 'really serious harm'. In causing grievous bodily harm, the act of sterilisation could constitute an aggravated assault offence, attracting one of the highest maximum penalties on the criminal calendar. ${ }^{8}$ Despite the potential seriousness of sterilisation as an aggravated assault offence, the law of assault provides that informed consent can render lawful the act of contact involved in a medical procedure, including sterilisation. In relation to a woman or girl with intellectual disability who is considered incapable of providing informed consent, informed consent can instead be given by the individual's parent or guardian where this consent has been made through a substituted decision making regime such as guardianship or the Family Court's welfare jurisdiction. This third party consent transforms what would otherwise constitute unlawful contact amounting to a serious criminal offence into consensual, lawful contact which is consequently outside of the realm of the law of assault. Therefore, sterilisation of women and girls with intellectual disability is legally permissible by reason of the operation of substituted decision making regimes and the need for the operation of these regimes is provided by the law of assault: the legal permissibility of sterilisation results from the interplay of criminal law with family law and guardianship law. The legal permissibility of legally authorised sterilisation was recently affirmed by the Senate Community Affairs References Committee ('the Committee') in its 2013 report, Inquiry Into the Involuntary or Coerced Sterilisation

${ }^{3}$ French et al (2009); Women With Disability Australia et al (2011); Australian Human Rights Commission (2012); Broderick (2012); Frohmader (2013).

${ }^{4}$ Méndez (2013) at [48]. See, generally, Frohmader (2013), p 70.

${ }^{5}$ Fagan v Metropolitan Police Commissioner [1969] 1 QB 439 at 444.

${ }^{6}$ While common assault is grounded in the common law, aggravated assault offences are legislatively based. See, for example, in the context of New South Wales, the Crimes Act 1900 (NSW), Pt 3 Div 8.

${ }^{7}$ DPP v Smith [1961] AC 290 at 334 (Viscount Kilmuir LC) (which is defined to include 'any permanent or serious disfiguring of the person'): Crimes Act 1900 (NSW) s 4 'grievous bodily harm'.

${ }^{8}$ For example, in the New South Wales statutory context, sterilisation could constitute the offence of 'grievous bodily harm with intent' which carries a maximum penalty of 25 years imprisonment: Crimes Act 1900 (NSW) s 33(1)(b). 
of People With Disabilities in Australia. ${ }^{9}$ The Committee recommended retaining and strengthening the existing legal frameworks for authorisation of sterilisation and criminalising only non-legally authorised sterilisation. ${ }^{10}$ Thus, legally authorised sterilisation looks set to continue being a legally permissible form of violence against Australian women and girls with intellectual disability.

In broadly agreeing with the argument advanced by Australian disability rights advocates that sterilisation is a form of violence against women and girls with disability, in this article the author draws out some of the finer details of this violence. Through doing so the author aims to offer a more nuanced understanding of the violence of sterilisation which can then inform future scholarship and advocacy arguing against the continuation of this practice. This article examines the significance of law to the violence done to women and girls through sterilisation, specifically through an analysis of the intersections of the law of assault and the Family Court's welfare jurisdiction in the legal permissibility of the sterilisation of girls ${ }^{11}$ with intellectual disability ('court authorised sterilisation'). The article's examination is done by reference to the concepts of 'legal violence' and 'abnormality'. 'Legal violence' refers to the idea of law as inherently violent through its implication in (rather than its absolute opposition to) physical force. 'Abnormality' refers to the idea of disability as constructed against social norms of human functioning and ability and this construction provides new openings for interventions in (and violence to) the bodies of people with disability under the benevolent guise of managing their deviations from social norms. Through an analysis of court authorised sterilisation by reference to these two ideas, the article argues that court authorised sterilisation of girls with intellectual disability is a form of lawful and 'good' violence against abnormal legal subjects. Girls with intellectual disability by reason of their incapacity are positioned outside the group of 'normal' legal subjects of assault who have the capacity to decide to consent to contact with their otherwise impermeable and legally sacrosanct bodies. As the girls with intellectual disability are deemed to constitute 'abnormal' legal subjects of assault, the lawfulness of the contact involved in the act of their sterilisation is not dependent on the consent of the girls themselves, but instead on the consent of their parents as authorised by the Family Court acting in its welfare jurisdiction. In the course of authorising parental consent to sterilisation, the Family Court not only renders an act of sterilisation lawful violence, but also 'good' violence through the characterisation of girls with intellectual disability who are sterilised as absolutely different to individuals without disability and through the characterisation of the act of sterilisation in legal, familial and medical terms. The article identifies the concept of 'good violence' from a critical sense, ${ }^{12}$ arguing that through constructing sterilisation as 'good' violence, law legitimates its actions of violence because the construction of legal violence as humane and beneficial masks its negative and harmful character. Ultimately,

\footnotetext{
${ }^{9}$ Senate Community Affairs References Committee (2013).

${ }^{10}$ Senate Community Affairs References Committee (2013), pp xiii-xiv.

${ }^{11}$ 'Girls' refers to female persons aged under 18 years.

${ }^{12}$ This approach to 'good violence' can be compared to a more literal and material approach to good violence pursuant to which the violence performed by law through sterilisation itself can and should be characterised as good.
} 
illuminating the legal characterisation of sterilisation as lawful and 'good' violence suggests that future scholarship and advocacy around sterilisation of women and girls with intellectual disability should consider contesting the underlying legal and medical discourses that produce the act of sterilisation and the subjects of sterilisation, as well as the legal frameworks that regulate this practice.

To date there has been little discussion of disability in the scholarship on legal violence $^{13}$ and there has been little discussion of legal violence in the context of the scholarship on sterilisation or the scholarship on violence against women with disability more broadly. ${ }^{14}$ As such, the key scholarly contributions this article makes are threefold. The article contributes a new dimension to the scholarship on sterilisation by highlighting the significance of intersections of criminal law and family law to the violence of sterilisation. The article contributes to critical legal scholarship by illuminating the significance of disability and abnormality to legal violence. The article also problematises foundational concepts of humanness capacity, consent and bodily inviolability - and their intersections with disability and gender. On a broad level this article opens up new avenues for theorising and critiquing the relationship between criminal law and violence against women and girls with disability.

The article begins by introducing the legal framework for court authorised sterilisation and illuminating the role of law through court authorisation in making the violence done to girls through sterilisation lawful. Next, the article examines how the law of assault provides the legal contours for sterilisation as lawful violence. The article then turns to discuss the relationship of girls with intellectual disability to these legal contours, arguing that the girls are abnormal legal subjects in relation to whom parents decide the violence done to the girls' bodies through sterilisation. The article shifts to the Family Court's welfare jurisdiction to argue that Family Court authorisation of sterilisation works within the contours of the law of assault and on the basis of the abnormality of girls with intellectual disability to render a specific act of sterilisation 'lawful violence' and, additionally, 'good violence'. The article concludes by urging greater engagement with and challenging of the relationships between disability, violence and criminal law.

\section{Family Court authorised sterilisation and legal violence}

Sterilisation of girls with intellectual disability is not a form of violence that always takes place illicitly and outside of legal recognition. Rather, there is an established legal framework for acts of sterilisation to be legally authorised. The current legal

\footnotetext{
${ }^{13}$ See, however, Alfieri's (1994) discussion of the legal violence involved in his client 'Wanda Field's' court matter related to an application for Supplemental Security Income for the Aged, Blind, and Disabled, based in part on her illiteracy (which was inextricably linked to her race and poverty); see also reference to sterilisation as legal violence in Hunter (2006), p 33. See also the references to state violence (which is described in terms which overlap with legal violence) and ableism in Spade (2011), pp 87-90, and the discussion of legal violence in the context of the civil law on medical treatment for individuals in 'vegetative' states in Wald (1995), pp 88-92.

${ }^{14}$ See, however, Hunter (2006, p 33) who has specifically identified court ordered sterilisation of young women with intellectual disability as a form of legal violence; see also Steele (2013).
} 
framework for court authorised sterilisation is found in Part VII of the Family Law Act 1975 (Cth). The majority of Part VII is concerned with making orders relating to the care and financial support of a child following the breakdown of his or her parents' relationship. The court's residual welfare jurisdiction pursuant to which the Family Court 'has jurisdiction to make orders relating to the welfare of children' is found in s 67ZC of the Family Law Act 1975 (Cth). While not explicitly mentioned in the Family Law Act 1975 (Cth), the High Court established in its decision of Secretary, Department of Health and Community Services v JWB (Marion's Case) that an order authorising the sterilisation of a child with intellectual disability can be made by the Family Court acting in its welfare jurisdiction. ${ }^{15}$

The Family Court's consideration of making an order authorising the sterilisation of a girl with intellectual disability is dependent upon two factors. The first factor is whether the girl is incapable of giving informed consent to the procedure. An individual is capable of giving informed consent when he or she achieves a sufficient understanding and intelligence to enable him or her to understand fully what is proposed'. ${ }^{16}$ If the girl is incapable of consenting, then the girl's parents can consent to the sterilisation instead. The second factor relates to the purpose of the sterilisation. Whether parental consent requires authorisation by the Family Court depends upon the purpose of the sterilisation - whether the sterilisation is therapeutic or non-therapeutic. If the sterilisation is 'therapeutic', that is, if it is a 'by-product of surgery appropriately carried out to treat some malfunction or disease', ${ }^{17}$ then the parents have the authority to consent on the girl's behalf to the sterilisation without seeking court authorisation. ${ }^{18}$ If the sterilisation is 'non-therapeutic', that is, other than a by-product of surgery for malfunction or disease, then sterilisation falls outside of the scope of parental authority and consequently the Family Court pursuant to s 67ZC must authorise the parental consent. ${ }^{19}$ Significantly, court authorised sterilisation is specifically sterilisation which is non-therapeutic. This means that violence against girls with intellectual disability through sterilisation is being authorised by the Family Court for reasons other than those related to serious medical issues.

Before making an order under s 67ZC in relation to the non-therapeutic sterilisation of a child with intellectual disability, the Family Court must be satisfied that the sterilisation is in the child's best interests and that there are no other alternative, less invasive procedures. Section $67 \mathrm{ZC}(2)$ provides that '[i]n deciding whether to make an order under [s 67ZC(1)]', the Family Court 'must regard the best interests of the child as the paramount consideration'. Generally, s 67ZC(2) provides factors to consider in relation to best interests that apply to all orders made under s 67ZC(1) and other provisions in Part VII of the Family Law Act 1975 (Cth).

\footnotetext{
${ }^{15}$ Secretary, Department of Health and Community Services $v$ JWB (1992) 175 CLR 218 (Marion's Case) at 254-259 (Mason CJ, Dawson, Toohey and Gaudron JJ) (referring to the previous provision s 64(1) of the Family Law Act 1975 (Cth) as it then was).

${ }^{16}$ Marion's Case at 237 (Mason CJ, Dawson, Toohey and Gaudron JJ), approving Gillick v West Norfolk AHA [1986] AC 112 at 183-184 (Lord Scarman).

${ }^{17}$ Marion's Case at 250 (Mason CJ, Dawson, Toohey and Gaudron JJ).

${ }^{18}$ Marion's Case at 250 (Mason CJ, Dawson, Toohey and Gaudron JJ).

${ }^{19}$ Marion's Case at 250 (Mason CJ, Dawson, Toohey and Gaudron JJ).
} 
Section 60CC elaborates on the 'best interests' of a child. The primary considerations are 'the benefit to the child of having a meaningful relationship with both of the child's parents' and 'the need to protect the child from physical or psychological harm from being subjected to, or exposed to, abuse, neglect or family violence', with the court being required to give greater weight to the second of the two considerations. ${ }^{20}$ Fourteen additional considerations are also specified ${ }^{21}$ which are similarly focused on factors primarily related to the parent/child relationship. However, the Family Court in Re Marion (No 2) ${ }^{22}$ outlined a number of relevant factors to consider in determining whether sterilisation would be in the best interests of a child. ${ }^{23}$ These factors are focused on the appropriateness of sterilisation viewed as a 'procedure or treatment', including the nature of and reasons for the treatment. The next consideration is that surgical sterilisation is a step of last resort; that is, 'alternative and less invasive procedures have all failed or that it is certain that no other procedure or treatment will work'. ${ }^{24}$ Once the Family Court is satisfied in regard to all of these factors, it can make an order pursuant to s 67ZC authorising parental consent to the sterilisation of a girl with intellectual disability. The effect of such an order is to enable the parents of the girl to give consent to the sterilisation procedure $^{25}$ and in doing so to render the act of violence of sterilisation legal despite the absence of the girl's consent.

On a general level, the family law framework can be understood by reference to legal violence. 'Legal violence' is a concept which directs analytical attention to the law's role in making the violence of court authorised sterilisation of girls with intellectual disability possible and legitimate. ${ }^{26}$ The idea of legal violence has its basis in the notion that all law is inherently violent ${ }^{27}$ and that physical force is implicated in (rather than external to and in absolute opposition to) law. At the core of the concept of 'legal violence' is a relationship between the 'word' of law (that is, the legal interpretation and the resulting judgement and court order $)^{28}$ - and a 'deed' of violence itself (that is, the act of non-legal/judicial actors administering the order). ${ }^{29}$ An example offered by Robert Cover is criminal punishment. Criminal punishment in the form of incarceration and loss of liberty can be analysed as legal violence because the punishment meted out by prison officers is done pursuant to the terms of

\footnotetext{
${ }^{20}$ Family Law Act 1975 (Cth) s 60CC(2A).

${ }^{21}$ Family Law Act 1975 (Cth) s 60CC(3).

${ }^{22}$ Re Marion (No 2) (1992) 17 Fam LR 336.

${ }^{23}$ Re Marion (No 2) (1992) 17 Fam LR 336.

${ }^{24}$ Marion's Case at 259 (Mason CJ, Dawson, Toohey and Gaudron JJ).

${ }^{25}$ Marion's Case at 262 (Mason CJ, Dawson, Toohey and Gaudron JJ), see also 317, 318 (McHugh J). This can be compared to Brennan J who dissented on whether the Family Court could authorise a non-therapeutic sterilisation and who was of the view that authorisation should not be viewed as substituted consent: Marion's Case at 267-268 (Brennan J).

${ }^{26}$ On legal violence generally, see Cover (1986); Sarat and Kearns (1992); Sarat (2001).

${ }^{27}$ Sarat and Kearns (1992), p 1; Sarat (2001), p 3.

${ }^{28}$ See also Alfieri's (1994) argument about the 'words' of lawyers involved in legal process leading up to the judge's decision.

${ }^{29}$ Cover (1986), p 1611.
} 
the words of the judge's sentence, and it is because the act of punishment is constrained by the words of this legal order that it is a legitimate use of violence in being fair, humane, just and non-arbitrary. ${ }^{30}$

The act or 'deed' of sterilisation is carried out by medical practitioners and is consented to by parents. Yet it is the legal order pursuant to s 67ZC itself, and the legislative framework for the making of this order, that make the deed of sterilisation possible as a legally permissible form of violence. The 'words' of the court order authorise parents to consent to medical practitioners carrying out the 'deed' of the sterilisation procedure. Violence against girls with intellectual disability through sterilisation is not absolutely prohibited by law. Rather, the violence of sterilisation is regulated by law. Thus, the violence of sterilisation has a legal character: it is lawful violence. Gaining a more complex understanding of court authorised sterilisation as lawful violence requires moving beyond the confines of the Family Court's welfare jurisdiction and the legal requirements for the authorisation of a particular act of sterilisation and turning to consider criminal law's role in providing the general legal contours of violence within which court authorisation operates.

\section{Consent and the contours of lawful violence}

Criminal law is significant to any consideration of violence, even that which is authorised in a different jurisdictional space (as is the case with court authorised sterilisation where the act of authorisation or the 'word' of the violence takes place in the family law jurisdiction). This is because criminal law is the jurisdiction through which the state prohibits acts of violence and hence the jurisdiction which defines unlawful violence. Conversely, acts of violence which are not prohibited by criminal law become forms of lawful violence. Thus, criminal law's prohibition of (some) violence means that other violence is not prohibited and is subsequently permitted: criminal law provides the contours, that is, the scope and limits, of lawful violence. ${ }^{31}$ These contours are central to the extent to which violence can (or needs to be) authorised in other jurisdictions. For present purposes it is necessary to turn to the criminal law of assault which deals with interpersonal physical contact ('contact').

Pursuant to the law of assault, generally it is unlawful for an individual to make contact with another individual with the intention of, or being reckless as to, the possibility of making such contact. ${ }^{32}$ Yet not all contact constitutes assault. There is a variety of exceptions where contact is lawful, including physical discipline of children, ${ }^{33}$ contact occurring in the course of ordinary social activity ${ }^{34}$ and

\footnotetext{
${ }^{30}$ Cover (1986), pp 1608-1609, 1618-1628; see also Wald (1995), pp 81-83.

${ }^{31}$ See, generally, Golder $(2004,2012)$.

${ }^{32}$ Fagan v Metropolitan Police Commissioner [1969] 1 QB 439 at 444.

${ }^{33}$ See, for example, in New South Wales, the Crimes Act 1900 (NSW) s 61AA.

${ }^{34}$ Collins v Wilcock [1984] 3 All ER 374; Boughey v R (1986) 161 CLR 10.
} 
consensual contact. This last exception is central to an analysis of the legal permissibility of court authorised sterilisation.

In certain circumstances consent to contact will render contact lawful and hence not assault. ${ }^{35}$ Generally, consent renders contact lawful when the contact amounts to common assault. ${ }^{36}$ Yet consent does not always negate assault where the contact occasions actual bodily harm or greater ('serious levels of harm'). ${ }^{37}$ As discussed earlier, sterilisation, which involves incisions to the body and the removal of, or alterations to, bodily organs, constitutes contact causing grievous bodily harm. The judiciary have incrementally carved out a series of miscellaneous categories of contact where individuals can give consent (implied or express) to serious levels of harm to render the contact lawful. These categories include violent or contact sports, ${ }^{38}$ fighting, ${ }^{39}$ tattooing ${ }^{40}$ and, relevant for present purposes, surgery.

Where an individual gives 'informed consent' to the contact involved in surgery, this contact is lawful and will not constitute an assault. ${ }^{41}$ Generally, in relation to the consent exception to assault, the consent must be given by the recipient of the contact (that is, the alleged victim). Yet in the specific context of surgery, if the alleged victim is incapable of giving consent, criminal law recognises the consent of a third party given on behalf of the individual as sufficient to render the contact lawful. ${ }^{42}$ Other jurisdictions, notably guardianship law and the Family Court's welfare jurisdiction, provide legal oversight to third party consent through substitute decision making regimes. ${ }^{43}$ In the context of the sterilisation of girls with intellectual disability who

\footnotetext{
${ }^{35}$ It is important to note that there is some contention in the UK commentary concerning whether the cases characterise consent as a defence or the absence of consent as an element of the actus reus of the offence of assault. See, for example, Simester et al (2010), p 428; Wells and Quick (2010), p 249; see also Moran (1995), pp 229, 233; $R$ v Brown [1994] 1 AC 212 at 246-247 (Lord Jauncey of Tullichettle).

${ }^{36} R$ v Brown [1994] 1 AC 212 at 231 (Lord Templeman), see also 244-245 (Lord Jauncey of Tullichettle).

${ }^{37} R v$ Coney (1882) 8 QBD 534 at 539 (Cave J), 549 (Stephen J); $R v$ Donovan [1934] 2 KB 498 at 507 (Swift J); Attorney-General's Reference (No 6 of 1980) [1981] QB 715 at 719 (Lord Lane CJ); $R$ v Brown [1994] 1 AC 212 at 231-234 (Lord Templeman). Actual bodily harm is defined as having 'its ordinary meaning and includes any hurt or injury calculated to interfere with the health or comfort of the prosecutor' which 'need not be permanent but must, no doubt, be more than merely transient and trifling': $R v$ Donovan [1934] 2 KB 498 at 509. Grievous bodily harm is more serious level of harm than actual bodily harm and is defined as 'really serious' harm: DPP v Smith [1961] AC 290 at 334 (Viscount Kilmuir LC).

${ }^{38} R$ v Billinghurst [1978] Crim LR 553.

${ }^{39}$ Attorney-General's Reference (No 6 of 1980) [1981] QB 715.

${ }^{40} R v$ Wilson [1996] 3 WLR 125.

${ }^{41} R v$ Brown [1994] 1 AC 212 at 231 (Lord Templeman), 243, 244-245 (Lord Jauncey of Tullichettle), 258-259, 266 (Lord Mustill).

${ }^{42}$ Marion's Case at 262 (Mason CJ, Dawson, Toohey and Gaudron JJ), see also 317, 318 (McHugh J). Note also that consent is not required if the surgery is conducted in an emergency: Bronitt and McSherry (2010), pp 592-593.

${ }^{43}$ In the context of family law, see Family Law Act 1975 (Cth) s 67ZC. For an overview of the relevant guardianship laws in the various Australia state and territory jurisdictions, see Senate Community Affairs References Committee (2013), pp 68-80. For an overview of the various state and territory guardianship jurisdictions more generally, see O'Neill and Peisah (2011) Ch 12, Ch 15.
} 
are considered incapable of consenting, it is the consent of their parents (as authorised by the Family Court) which places the act of sterilisation outside of the law of assault and renders sterilisation an act of lawful violence. This is the place at which the criminal law of assault and the Family Court's welfare jurisdiction intersect in relation to the legal permissibility of sterilisation of girls with intellectual disability. $^{44}$

Therefore, while generally individuals with capacity control the violence done to their bodies (to the extent that the withholding of consent renders contact nonconsensual and hence assault), third parties (albeit with legal oversight through substitute decision making regimes) control the violence done through surgery to individuals without capacity, including the violence done through sterilisation to girls with intellectual disability. In order to gain an even more complex understanding of court authorised sterilisation as lawful violence, it is necessary to take a closer look at consent.

\section{Consent and the differential lawfulness of violence}

Criminal law's regulation of violence through assault is not universal in its operation - not every individual's experience of contact is equally recognised as an act of unlawful violence and not every individual's experience of consensual contact is equally recognised as an act of lawful violence. Instead, the criminal law of assault operates differentially depending on who is involved and what the circumstances of the contact are. In general, the reason criminal law limits the lawfulness of consensual contact per se to common assault is that more serious levels of harm injure not only the individual, but also the public because they involve a breach of the peace. ${ }^{45}$ In the realm of serious levels of harm, the categories of consensual contact have all been carved out of the law of assault on the basis of the contact and related harm being 'in the public interest' and for 'good reason'. ${ }^{46}$ For example, informed consent to surgery is sufficient to render that contact lawful on the basis that surgery is 'needed in the public interest'. 47

The centrality of 'public interest' to the lawfulness of an act of violence indicates that the law of assault is not abstracted from social and moral interests but is informed by and furthers these interests: the criminal law of assault is contingent

\footnotetext{
${ }^{44}$ Whereas criminal law is 'reactive' in responding to unlawful acts of contact, the Family Court is 'prospective' in providing the consent to contact to prevent these acts of contact being unlawful and hence outside the reach of reactive criminal law: Bridgeman (1995), p 133. This is slightly different to the Family Court determining unlawfulness and providing declaratory relief to this effect, but rather it provides one aspect to avoid the elements of the offence. On this relationship generally, see Bridgeman (1995).

${ }^{45}$ See, for example, $R v$ Coney (1882) 8 QBD 534 at 549 (Stephen J), see also 553 (Hawkins J), 567 (Lord Coleridge CJ).

${ }^{46}$ Attorney-General's Reference (No 6 of 1980) [1981] QB 715 at 719 (Lord Lane CJ).

${ }^{47}$ Attorney-General's Reference (No 6 of 1980) [1981] QB 715 at 719 (Lord Lane CJ).
} 
upon social norms. For example, it is in the public interest that assault occasioning actual bodily harm can be consented to for traditionally masculine pastimes such as violent sport and fighting, and even the branding of a consenting female sexual partner may be considered acceptable where healing was deemed to be 'normal'. ${ }^{4}$ On the other hand, it has been held not in the public interest that assault occasioning actual bodily harm can be consented to for sadomasochistic activity between homosexual males (or between heterosexual partners). ${ }^{49}$ These examples not only highlight the significance of social norms (notably norms of gender and sexuality) to the law of assault, additionally they highlight how the law of assault's contingency to these norms results in the differential lawfulness of violence between different groups of individuals both in regard to who can perpetrate lawful violence and who can be protected from unlawful violence (for example, in general terms, heterosexual men versus homosexual men). ${ }^{50}$

The differential lawfulness of violence means that certain groups of individuals whose identities and/or conduct reinforce social norms experience greater state protection from violence and are afforded legal recognition of their autonomy to consent to violence ('normal' subjects of assault). On the other hand, other groups of individuals whose identities and/or conduct deviate from social norms experience lower state protection from violence and are afforded less legal recognition of their consent to acts of violence ('abnormal' subjects of assault). ${ }^{51}$ Importantly, abnormal legal subjects are not completely beyond the reach of criminal law such that they can be lawfully subject to all acts of violence. Rather, the regulation of violence by criminal law in relation to this group is linked to the enforcement of social norms either by condoning as lawful contact of a norm-deviating individual when this contact will manage deviations from social norms or refusing to acknowledge consent to contact made by a norm-deviating individual (for example, a medical procedure to 'correct' an intersex individual), or punishing as unlawful violence contact by a norm-deviating individual when this act constitutes a deviation from social norms (e.g. punishing, as assault, consensual sadomasochistic homosexual behaviour).

\section{Girls with intellectual disability as abnormal subjects of assault}

The discussion above has highlighted the significance of social norms relating to gender and sexuality to the law of assault. It is argued in this section that the law of

\footnotetext{
${ }^{48}$ Re fighting (including professional prize fighting), see $R v$ Coney (1882) 8 QBD 534, 539 (Cave J), 549 (Stephen J); Attorney-General's Reference (No 6 of 1980) [1981] QB 715 at 719 (Lord Lane CJ). Re consensual sadomasochism (and consent), see $R$ v Donovan [1934] 2 KB 498 at 507 (Swift J); $R$ v Brown [1994] 1 AC 212 at 231-234 (Lord Templeman); $R v$ Wilson (1966) Crim LR 573, but see $R v$ Emmett (unreported [1999]) EWCA Crim 1710 (18 June 1999). Re parental chastisement, see $R v$ Billinghurst [1978] Crim LR 553.

${ }^{49}$ Re homosexual consenting adults, see $R v$ Brown [1994] 1 AC 212 . Re heterosexual consenting partners, see $R v$ Emmett (unreported [1999]) EWCA Crim 1710 (18 June 1999).

${ }^{50}$ See similar point made by Golder $(2004,2012)$ in the context of murder.

${ }^{51}$ See, for example, Bibbings (2000), pp 237-243; see, generally, Moran (1995). On the relationship between gender, sexuality, violence and criminal law more broadly, see Golder (2004, 2012).
} 
assault is also contingent to norms of ability. Furthermore, these norms of ability intersect with norms of gender and sexuality in relation to the legal permissibility of the violence done to girls with intellectual disability through acts of sterilisation. Appreciating the significance of social norms of ability to assault is possible by reference to the concept of 'abnormality'. Disability is typically seen as a condition that resides within an individual and is measured by the extent to which that individual falls short of an objective norm of physical, mental or cognitive functioning. ${ }^{52}$ From this perspective norms can be seen as biological rather than social, and any differences between individuals are to be expected as natural and unchangeable by reason of inherent differences. Yet, critical disability scholars argue that disability can instead be approached analytically as a socially constructed 'abnormality'. ${ }^{53}$ That is, it is against social ideals, rather than biological norms, of human functioning and ability that disability becomes 'abnormal' and that disability can even exist per se and as a socially undesirable state of human existence. Feminist and queer critical disability scholars have also noted the intersection of ability norms with norms of gender and sexuality. ${ }^{54}$ Being labelled as 'disabled' provides openings into forms of 'fixing' or managing an individual's purported biological 'abnormality', particularly (by reason of the purportedly biological nature of disability) through medical interventions. Such interventions are framed in humane, therapeutic and empowering terms, because abnormality is inherently negative. ${ }^{55}$ It is desirable to eradicate, minimise or manage an individual's abnormality and its effects, even through the use of what would be considered violence if done to 'normal' individuals.

By utilising the concept of abnormality to examine the law of assault, it is possible to analyse how the law of assault is contingent to social norms of ability (including the intersection of these norms with norms of gender and sexuality), specifically those of an 'impermeable body' and a 'capable mind'. ${ }^{56}$ At the very core of the criminal law of assault is the principle of bodily inviolability and this is informed by norms of ability, as well as gender and sexuality. As stated in Collins $v$ Wilcock: ${ }^{57}$ 'The fundamental principle, plain and incontestable, is that every person's body is inviolate. It has long been established that any touching of another person, however slight, may amount to a battery'. ${ }^{58}$ Through the principle of bodily inviolability, the criminal law of assault reflects two social norms. One of these social norms is an impermeable body: the body is closed and self-contained and distinct from other bodies ${ }^{59}$ and there are distinct boundaries between individuals which render the body 'impermeable'. ${ }^{60}$ The other social norm is a 'capable mind': the

\footnotetext{
${ }^{52}$ Allen (2005), p 94.

${ }^{53}$ See, for example, Corker and French (1999); Corker and Shakespeare (2002); Tremain (2002, 2005); Campbell (2009); Shildrick (2009).

${ }^{54}$ See, generally, Shildrick (2009); Desjardins (2012); McRuer and Mollow (2012).

${ }^{55}$ Hall (2011), p 4.

${ }^{56}$ Naffine (2009), p 149.

${ }^{57}$ Collins v Wilcock [1984] 3 All ER 374.

${ }^{58}$ Collins v Wilcock [1984] 3 All ER 374 at 378.

${ }^{59}$ Naffine (1997), pp 84-85; Golder (2004), pp 57-58; Savell (2004), p 1106; Naffine (2009), p 148. On legal boundaries and autonomy generally, see Nedelsky $(1989,1990)$.

${ }^{60}$ Scarry (1990), p 868.
} 
permeation of one's body by another is governed by the mind of the individual of that body. These two social norms combine in the legal concept of consent: the act of consent communicates a conscious decision in regard to when an individual's body can be permeated by another. ${ }^{61}$

The social norms of impermeable body and capable mind do not encapsulate all embodied individuals stretching across the spectrum of human attributes and experience. Individuals with cognitive incapacity will be considered as deviating from these social norms in lacking both the ability to make decisions about contact with their bodies and the ability to control the boundaries of their bodies. It is on the basis of the significance of norms of ability (and their intersection with norms of gender and sexuality) that girls with intellectual disability become abnormal legal subjects of assault, in relation to whom sterilisation becomes a form of lawful violence.

First, girls with intellectual disability deviate from the social norm of a capable mind. The principle wrong of assault is not so much the violence done to the body per se, but rather the incursion on an individual's right to choose what happens to his or her body, ${ }^{6}$ or as Nicola Lacey states in the context of consent and sexual assault: "the choice to exclude another from access to bodily "property". ${ }^{63}$ Yet, as Ngaire Naffine notes: 'Several negative implications can be drawn about law's physical person. Implicitly, his reason is not clouded by sickness or pain, his mind is not impaired by mental illness or disability; he is not pregnant and he is not in labour; he is not a baby or a child ...; he is not even explicitly sexed'. ${ }^{64}$ Girls with intellectual disability by reason of their perceived impairments in cognition deviate from the social norm of capacity and in turn the ability to exercise autonomy over their body through deciding who has contact with their bodies.

Second, girls with intellectual disability also deviate from the social norm of the impermeable body. As Elaine Scarry notes, while consent occurs through an act of the mind it is the body which is ultimately protected from violence and hence there must be a legitimate body capable of being protected. ${ }^{65}$ It has been argued that this body of the normal subject of assault is based on gendered and sexual norms of the

\footnotetext{
${ }^{61}$ Naffine describes the centrality of these two social norms to the law of assault as follows: '[...] we can discover at the heart of the law of human contact is a quite particular idea of a bounded, embodied subject, ... the person presupposed by the law of assault is a discrete, distinct, volitional subject for whom the skin of his body is considered to represent a boundary from other distinct subjects ... People are essentially bounded and separate, they come in closed body bags, and it is vital that one person not interfere with the body bag of another unless there is a positive agreement to make contact': Naffine (1997), p 84; see, generally, pp $84-85$.

${ }^{62}$ Lacey (1998), pp 57-58; see also Lacey (2000), pp 96-97. See also the distinction between mind and body in the context of the defendant and the primacy of mens rea as a rationale for criminal responsibility and punishment in Lacey (1997), p 73; Lacey (1998), pp 54-62; Rollinson (2000).

${ }^{63}$ Lacey (1998), p 59.

${ }^{64}$ Naffine (2009), p 144.

${ }^{65}$ Scarry (1990), p 871.
} 
male body. ${ }^{6}$ Some writers argue that, despite the various ways in which the heterosexual male body is permeable (such as semen, urine and faecal emissions), female bodies are legally constructed as inherently permeable through sexual intercourse, menstruation, childbirth and breastfeeding (whilst others argue that homosexual men are likewise permeable due to an openness to anal intercourse and similarly not according with the male heterosexual norm) ${ }^{67}$ In such a view, if the female body, however, is already considered 'permeable', women and girls do not have a closed body that is permeated only through consent to specific acts, but instead one that is already and always open to others, and notably in matters relating to sexuality. ${ }^{68}$ Naffine argues that "women in such circumstances somehow have a reduced status as persons because their body bag, their skin, has been punctured and permeated'. ${ }^{69}$ They are the other to the human read as male. This renders more permissible contact done to women's already permeable bodies because in not being like male heterosexual bodies, both they and male homosexual bodies are "somehow deviant and undeserving bodies. They are "unnatural", even "loathsome", because they have apparently lost their clear definition'. ${ }^{70}$

Yet, in addition to their permeability by dint of being female, girls with intellectual disability can be considered to have hyper-permeable bodies because they are viewed as having reduced cognitive and physical ability to self-regulate their permeability. ${ }^{71}$ Moreover, their dependence upon others for support in self-care shows the fundamental interconnectedness of these girls with others and hence their inability to exhibit bodily separation from others which is central to autonomy. ${ }^{72}$ By reason of the failure of girls with intellectual disability to meet female gendered norms of self-regulation, their impermeable bodies also reflect norms at the intersection of gender, sexuality and ability - the norms of ability, gender and sexuality are, in the words of Kendall Thomas, 'inter-articulated and embedded in one another'. ${ }^{73}$ This hyper-permeability of the bodies of girls with intellectual disability underpins the permissibility of lawful contact aimed at reinforcing gender, sexuality and ability norms related to management of the body.

\footnotetext{
${ }^{66}$ As Naffine (1997, p 86) states: 'What the criminal law of human contact presupposes is a standard, uniform, bounded human body which is really an extrapolation from a certain liberal conception of the male body, not a woman's body'..

${ }^{67}$ Savell (2004), pp 1106-1197; see also Golder (2004) who notes that the body of criminal legal subject is not only male, but more specifically heterosexual male due to the permeability of the homosexual body.

${ }^{68}$ See, for example, Naffine (2009), p 156 (and subsequent elaboration in the context of pregnancy, pp 157-160).

${ }^{69}$ Naffine (1997), p 86.

${ }^{70}$ Naffine (1997), p 84.; see also Golder (2004), pp 59-60.

${ }^{71}$ As Naffine (2009, pp 158-159) observes: '[t]hey demonstrate a palpable failure to keep their bodies intact, to demonstrate bodily integrity with its associated dignity'.. On the 'leakiness' of children with disability, see Goodley and Runswick-Cole (2013). On the 'leakiness' of women with disability, see Shildrick (1997, 2002). See also Hall (2011), p 5, Garland-Thomson (2011), p 20.

${ }^{72}$ Naffine (2009), p 149, see also p 155.

${ }^{73}$ Thomas (2005), p 509.
} 
While it is acknowledged that all children require care and assistance, the level necessarily provided to girls with intellectual disability is viewed as exceeding that typically provided to children without intellectual disability. Moreover, girls with intellectual disability are often viewed as overly sexual and visceral (for example, playing with menstrual blood and used sanitary pads, vulnerable to sexual assault, sexually promiscuous, overly friendly with strangers, menstruating early, unable to regulate toileting) such that their bodies are hyper-permeable compared to children without disability. In relation to their inability to give consent, while all children have reduced decision making abilities as compared to 'normal' adults, children without intellectual disability are assumed to be constantly developing towards full adult levels of capacity, whereas children with intellectual disability (who are typically referred to in age equivalents and infantilised as eternal children) are effectively 'frozen in time' as 'children' and deviate from age-related norms of decision making ability. In this respect, girls with intellectual disability deviate from age-specific norms of ability, gender and sexuality.

In deviating from social norms related to ability, gender and sexuality, girls with intellectual disability are positioned outside of the group of normal legal subjects of assault and are instead abnormal legal subjects. The violence against them through sterilisation is not unlawful when they do not consent (as it is for 'normal', capable legal subjects), because these girls cannot consent. Yet this does not mean that they are completely beyond the scope of the law of assault. Instead, they are subject to the differential application of the law of assault as abnormal legal subjects of assault. Incapacity provides a different basis for violence ${ }^{74}$ and opens up new possibilities for the basis on which violence that is done to them is legally permissible. ${ }^{75}$ Thus, while the violence of sterilisation done to girls with intellectual disability seems to be completely at odds with the standards of permissible violence against normal, capable subjects of assault who have ultimate control over contact made with their bodies, the focus is now on what is in the incapable individual's best interests rather than recognising his or her individuality per se and engaging directly with that individual and what they want. ${ }^{76}$ The focus on best interests in third party consent suggests that the violence of sterilisation is linked to managing the girls' deviations from social norms (for example, sterilisation to prevent pregnancy, prevent inappropriate behaviour related to menstruation and fear of blood, prevent parents having to be involved in menstruation self-care, prevent a child being born from sexual assault).

Therefore, the law of assault reinforces and valorises individuals meeting social norms of ability through prohibiting the contact of sterilisation except when the normal, capable individual (him or herself) consents to this contact, and devalues girls with intellectual disability who do not meet these norms by rendering sterilisation lawful when parental consent to the procedure is authorised by the Family Court. ${ }^{77}$ The unlawfulness of the violence of sterilisation now turns on the

\footnotetext{
${ }^{74}$ Keywood (1995), p 144; Méndez (2013) at [66].

${ }^{75}$ Lacey (1998), p 61.

${ }^{76}$ Naffine (2009), pp 66, 69, 82, 92.

${ }^{77}$ On devaluation and abnormality generally see, for example, Garland-Thomson (2011), pp 17-18. For a similar point made in the context of rights and citizenship, see Carey (2009), p 216.
} 
presence or absence of Family Court authorisation of parental consent, rather than the girls' consent, thus enabling different individuals and different factors to determine the violence done to girls with intellectual disability through sterilisation as compared to children without disability.

\section{Court authorised sterilisation as lawful violence}

Family Court authorisation of a specific instance of parental consent to an act of sterilisation operates within the legal contouring of violence provided by the law of assault. This is demonstrated through the majority reasoning in the High Court decision Marion's Case. This decision concerned the Family Court's jurisdiction to authorise a sterilisation procedure on a girl with intellectual disability. Central to the decision is a consideration of the relationship between Family Court authorisation and the assault provisions in the Criminal Code 1983 (NT). The majority's judgment begins with the premise of bodily inviolability; that is, 'the right in an individual to choose what occurs with respect to his or her own person'. ${ }^{78}$ Thus, the majority's judgment is premised on the same notion of the individual controlling what occurs to his or her own body, which is at the core of assault law. Related to the principle of bodily inviolability is the concept of consent. Mason CJ, and Dawson, Toohey and Gaudron JJ state that '[c]onsent ordinarily has the effect of transforming what would otherwise be unlawful into accepted, and therefore acceptable, contact'. ${ }^{79}$ They additionally note the exception in relation to consent to surgery. This is that the patient must have the capacity to consent, which includes the capacity to understand the medical treatment the subject of the alleged assault stating that: 'Medical treatment of adults with full mental capacity' is 'lawful when it would otherwise be an assault' by reason of the consent of the patient. ${ }^{80}$ They cite the American decision of Schloendorff $v$ Society of New York Hospital ${ }^{81}$ which states that: 'Every human being of adult years and sound mind has a right to determine what shall be done with his own body; and a surgeon who performs an operation without his patient's consent commits an assault'. ${ }^{82}$ Therefore, the majority's decision on Family Court authorisation of specific acts of sterilisation is informed by the legal contouring of violence through law of assault: the lawfulness of consensual contact and the specific category of consensual surgery.

Moreover, the majority's decision is further informed by assault law's contouring of violence through recognising the differential lawfulness of violence between normal, capable ('legally competent') and abnormal, incapable legal subjects. The majority conclude that: 'Sterilisation comes within the category of medical treatment to which a legally competent person can consent' ${ }^{83}$ The majority note that children

\footnotetext{
${ }^{78}$ Marion's Case at 233 (Mason CJ, Dawson, Toohey and Gaudron JJ); see also 309-310 (McHugh J).

${ }^{79}$ Marion's Case at 233 (Mason CJ, Dawson, Toohey and Gaudron JJ).

${ }^{80}$ Marion's Case at 234 (Mason CJ, Dawson, Toohey and Gaudron JJ); see also 310 (McHugh J).

${ }^{81}$ Schloendorff v Society of New York Hospital (1914) 105 NE 92.

${ }^{82}$ Schloendorff v Society of New York Hospital (1914) 105 NE 92 at 93 (Cardozo J).

${ }^{83}$ Marion's Case at 234 (Mason CJ, Dawson, Toohey and Gaudron JJ).
} 
with intellectual disability actually fall outside the scope of this exception to assault because they are incapable of consenting. This is evident when the majority states: 'But what of medical treatment of those who, because of incapacity, cannot consent? What, besides personal consent, can render surgical intervention lawful?'. ${ }^{84}$ Therefore, the majority reiterates bodily inviolability and individual consent as central to the lawfulness of violence, but then positions girls with intellectual disability outside this framework because of their incapacity.

The majority shift to consider the possibility of the violence of sterilisation as lawful on the basis of the consent of a third party. After considering the power of parents, as guardians of children, to consent to medical treatment, ${ }^{85}$ the majority is of the view that sterilisation is a special case, outside the ordinary scope of parental power to consent to medical treatment. ${ }^{86}$ The majority thus concludes that the most appropriate framework is for Family Court authorisation of parental consent to sterilisation on behalf of their child. ${ }^{87}$ The majority concludes that this legal framework is grounded in bodily inviolability: "[T]he conclusion relies on a fundamental right to personal inviolability existing in the common law, a right which underscores the principles of assault, both criminal and civil, as well as on the practical exigencies accompanying this kind of decision which have been discussed' ${ }^{88}$ Yet two things are clear. First, the standard principle of bodily inviolability has been circumvented in relation to court authorised sterilisation because children with intellectual disability do not meet the mental requirements upon which inviolability of the body rests. Second, the reference to the "practical exigencies' seems to suggest that the circumvention of the notion of bodily inviolability by the majority in Marion's Case rests on the features particular to the situation of children with intellectual disability. ${ }^{89}$

Therefore, Marion's Case, which decided the Family Court had jurisdiction to authorise parental consent to sterilisation, was clearly located in the legal contours of violence provided by the law of assault. Importantly, court authorised sterilisation as lawful violence follows from the intersections of criminal law and family law: criminal law provides the possibility for lawful violence where informed consent is given by a third party to a medical procedure and family law provides that the Family Court can authorise parental consent in its welfare jurisdiction. At the core of this intersection is the differential lawfulness of violence which follows from the construction of girls with intellectual disability as incapable and hence abnormal. These findings have significant implications for scholarship on sterilisation as a form of violence against girls with intellectual disability. These findings direct critical attention to the central, ordering role of criminal law in what violence is legally possible and permissible, to foundational concepts in criminal law such as consent,

\footnotetext{
${ }^{84}$ Marion's Case at 234 (Mason CJ, Dawson, Toohey and Gaudron JJ).

${ }^{85}$ Marion's Case at 235-249 (Mason CJ, Dawson, Toohey and Gaudron JJ).

${ }^{86}$ Marion's Case at 249 (Mason CJ, Dawson, Toohey and Gaudron JJ); see also 253 (Mason CJ, Dawson, Toohey and Gaudron JJ).

${ }^{87}$ Marion's Case at 262 (Mason CJ, Dawson, Toohey and Gaudron JJ).

${ }^{88}$ Marion's Case at 253 (Mason CJ, Dawson, Toohey and Gaudron JJ).

${ }^{89}$ For a detailed critique of these 'practical exigencies', see Steele (2008).
} 
capacity and bodily inviolability, and to the construction of disability as abnormality in criminal law and family law.

\section{Sterilisation as 'good' violence}

While the intersections of the law of assault and family law render court authorised sterilisation of girls with intellectual disability a form of lawful violence, the particular nature of the Family Court's jurisdictional and legal framework for authorising specific acts of sterilisation additionally renders court authorised sterilisation of girls with intellectual disability a form of 'good' violence. In his discussion of legal violence, Leslie Moran draws a distinction between 'bad violence', that is, violence which occurs outside of the law, and the 'good violence' of legal violence. He argues that it is not simply the case that law has an oppositional relationship to violence, but rather that violence itself has a dual nature, and law opposes itself to 'harmful or bad violence' while being itself capable of 'beneficial violence or good violence'. ${ }^{90}$ Thus, while there might be little distinction between 'good' and 'bad' violence in relation to the nature of the act of physical force involved, the distinction instead lies in the relationship of the act to the law, with legitimate 'good' violence being that which is done pursuant to a rational legal process for the benefit of the community' and 'bad' violence being that which is done contrary to law and legal process and, in turn, is deemed a threat to the community. The article identifies the concept of 'good violence' from a critical sense, arguing that through constructing sterilisation as 'good' violence, law legitimates its actions of violence because the construction of legal violence as humane and beneficial masks its negative character. ${ }^{92}$ This section considers the extent to which court authorised sterilisation is 'good' violence by examining the Family Court's construction both of girls with intellectual disability and the act of sterilisation.

\section{Absolute difference and incomprehensibility of bad violence}

The violence done to girls with intellectual disability cannot be comprehended as 'bad' violence in the same way it would be if 'normal' girls were being sterilised. This is because girls with intellectual disability, by reason of their abnormality, are constructed as absolutely different and hence incomparable to 'normal' girls. The abnormality of the subject of sterilisation is vividly illustrated in Family Court sterilisation decisions which involve detailed consideration of the facts of particular sterilisation applications (as compared to the High Court's decision in Marion's Case which was more concerned with questions of law than the particular facts of Marion). In these decisions girls with intellectual disability are constructed as having 'leaky' bodies which they cannot control and hence as breaching bodily norms of impermeable bodies and female gendered norms of self-management of permeation: they cannot control or manage (nor can they fully mentally comprehend) their menstruation, sexual intercourse and fertility, nor can they manage their toileting

\footnotetext{
${ }^{90}$ Moran (1995), p 234; see also Pugliese (2013), pp 6-8.

${ }^{91}$ Moran (1995), p 234; see also Wald (1995), p 78.

${ }^{92}$ Moran (1995), p 234.
} 
and general self-care and hygiene, and are deemed to be generally 'out of control' in terms of their behaviour. ${ }^{93}$ These girls thus become abnormal not only because they fail to meet these norms of bodily regulation but also because the regulation concerns aspects of sexuality and toileting which 'are associated with the baser dimensions of being human; they are the functions which bring us closer to animals and so must be carefully directed and controlled'. ${ }^{94}$ These girls reflect what Naffine refers to as the 'potentially disruptive body, which must be contained and managed so as not to interfere with the exercise of reason'. ${ }^{95}$ They are constructed in terms of pathological abnormality ${ }^{96}$ at the intersections of norms of ability, gender and sexuality, ${ }^{97}$ and together these legal representations of girls with disability as hyperpermeable and out of control rationalise the violence done to girls with intellectual disability. ${ }^{98}$ The intervention through sterilisation to surgically manage (in lieu of self-management of) their hyper-permeability self-evidently follows from the abnormality. ${ }^{99}$ Therefore, in family law, girls with intellectual disability who are sterilised pursuant to court order are an absolutely different category of legal subjects. Their absolute difference follows from their construction as abnormal by reason of their deviations from gender, ability and sexuality norms. ${ }^{100}$ These deviations follow from their incapacity to consent to surgery and their incapacity to manage their hyperpermeable bodies.

As abnormal legal subjects and the absolute others to children without disability, girls with intellectual disability are incapable of being compared to children without disability. As such the violence of sterilisation of girls with intellectual disability is beyond legal comparison to forms of violence against children without disability and hence cannot be comprehended as a discriminatory practice against girls with

\footnotetext{
${ }^{93}$ See, for example, Steele (2008). On the 'leakiness' of children with disability more generally, see Goodley and Runswick-Cole (2013). On the 'leakiness' of women with disability more generally, see Shildrick $(1997,2002)$; see Kafer (2013), pp 55-66 in the context of the US case of 'Ashley X'.

${ }^{94}$ Naffine (2009), p 147.

${ }^{95}$ Naffine (2009), p 147.

${ }^{96}$ Keywood (1995), pp 125, 130-131; Keywood (2002), p 29.

${ }^{97}$ They also breach norms of temporality at the intersection of gender, sexuality and age insofar as their minds are developing at a slower rate than their bodies: see point made by Kafer (2013, pp 48-49, 53-57) in the context of the US case of 'Ashley X'; see also Kittay (2011). See also Savell (2004, pp 1097-1098) in the context of the castration sterilisation of a male with intellectual disability. As Goodley and Runswick-Cole (2013, p 2) state: 'Children with impairments may challenge norms and goals associated with expected child development and psychological standards of what counts as a maturing body'..

${ }^{98}$ See, for example, Garland-Thomson (2011), p 21; see also Hall's (2011, p 6) similar point in the context of the US case of 'Ashley X'.

${ }^{99}$ Alison Kafer (2013, p 27) refers to this as the 'curative imaginary' that is there is 'an understanding of disability that not only expects and assumes intervention but also cannot imagine or comprehend anything other than intervention'..

${ }^{100}$ Given the historical centrality of race to sterilisation, it is acknowledged that this article has not engaged with the question of the presence or absence of race (including whiteness) in the judicial representations of the sterilised girls. See, for example, Williams in Kafer (2013), p 66. On the history of race and sterilisation in the US context, see Jarman (2012). However, none of the families in the 2001 Australian Human Rights Commission Report indicated Indigeneity: Brady et al (2001) Ch 3.
} 
intellectual disability. This inability to compare different categories is evident in the sterilisation case of $\operatorname{Re} P^{101}$ in which the full Family Court, in considering and affirming Marion's Case, rejected a 'but for' test in determining court applications for sterilisation-related orders; that is, comparing people with disability to those without disability (that is, but for the disability, would $\mathrm{X}$ be sterilised?). This was on the basis that disability is an 'immutable' characteristic. ${ }^{102}$ The reference here to 'immutable' suggests that disability is an unchangeable and natural phenomenon, rather than socially contingent, and one which is inherent to the very self in order to render an individual fundamentally different and incomparable to someone without a disability and hence in an absolutely different relation to the norms that order violence. Thus, the particular modes of violence in sterilisation become viewed as natural and inevitable because they are linked to seemingly inherent characteristics of girls with intellectual disability. What is evident in this example from $\operatorname{Re} P$ is not only the abnormality of the subjects of sterilisation, but how this 'self-evidently' renders permissible violence aimed at managing their deviations from norms of gender, sexuality and ability which manifest in the conduct of the girls related to their reproductive, menstrual and sexual capabilities in their un-sterilised state and which can be addressed through the sterilisation procedure. Therefore, the abnormality of girls with intellectual disability means that sterilisation cannot be comprehended as discriminatory 'bad violence'. It is suggested that the significance of abnormality to preventing comparison with girls without disability has important implications for utilising discrimination arguments in challenging the violence of sterilisation, and invites greater scholarly attention to the relationship between discrimination law and the construction of disability as abnormality.

\section{The benevolence of the act of sterilisation}

The second way in which court authorised sterilisation becomes 'good violence' is through the characterisation of sterilisation as a benevolent act. This comes about through three dimensions of its characterisation: legal procedural; medical; and familial.

(1) Legal procedural. Austin Sarat argues that the law holds a monopoly over what forms of violence are considered legitimate acts of force ${ }^{103}$ and does this in part through producing legal violence as being performed subsequent to a rational legal purpose and as benefitting society at large. ${ }^{104}$ Authorisation by the Family Court purports to transform the potential arbitrary, unnecessary, irrational and disproportionate violence of non-court authorised sterilisation into a just, measured and protective intervention by the legal system in a private and lawless realm of violence.

\footnotetext{
${ }^{101} \operatorname{Re} P(1995) 126$ FLR 245.

${ }^{102}$ 'We are unconvinced that there is any relevant conclusion to be drawn with regard to the best interests of a particular child by an artificial exercise which compartmentalises a finding of fact about an immutable characteristic and then hypothesises that it were not so': Re P (1995) 126 FLR 245 [emphasis added]. These ideas surface again in the recent Senate inquiry's rejection of a 'but for' test as opposed to a 'best interests' test: Senate Community Affairs References Committee (2013), p 131.

${ }^{103}$ Sarat and Kearns (1992), p 4.

${ }^{104}$ Sarat (2001), p 6; see also Sarat and Kearns (1992), pp 3-4.
} 
This is evident in the majority in Marion's Case, who refer to court authorisation as necessary 'in order to ensure the best protection of a child' and observe that such authorisation is 'a procedural safeguard' ${ }^{105}$ Thus, the violence of the law protects girls with intellectual disability against the unregulated and potentially arbitrary, dangerous and unnecessary violence of unauthorised sterilisation. It follows that what the girls are being protected from through court authorisation is the 'bad violence' of non-court authorised sterilisation which occurs outside of the law, rather than the violence of sterilisation per se. Moreover, through court authorised sterilisation the state is also protected from the 'bad' violence that unauthorised sterilisations do to the legal system insofar as these unauthorised procedures represent failures of parents to obey criminal law. This is evident in the recent Senate Community Affairs Reference Committee recommendations which focus on strengthening the framework for court authorised sterilisation, accompanied by criminalising procedures not authorised. ${ }^{106}$ This suggests that the crime is against the justice system (the failure to follow proper legal process as a preliminary to an act of violence) rather than against the individual per se (the act of violence regardless of the legal process). As Hunter notes, 'law seeks to monopolise violence not in order to protect legal subjects, but to protect itself from challenge'. ${ }^{107}$ In particular, the lack of capacity characterises them as vulnerable by reason of their incapacity and hence at risk of being exposed to violence being done to their bodies by individuals taking advantage of this incapacity. This in turn opens up possibilities for legally sanctioned violence which protects the individual from this 'bad violence' - that is, open to protective measures where violence is framed as being for the good or best interests of the individual. ${ }^{108}$

(2) Medical. The second way in which the violence of court authorised sterilisation is constructed as 'good' violence is through the framing of the act of sterilisation as a medical surgical procedure. Sterilisation is consistently referred to as a 'procedure', including in the context of the best interest factors specified in the decision of Marion (No 2). This word has a clinical, objective and measured manner to it. ${ }^{109}$ Moreover, the references to sterilisation as surgical and medical neutralise its violence in terms of it being scientifically objective, benign and therapeutically beneficial ${ }^{110}$ (at the same time that it is, seemingly contradictorily, acknowledged to be

\footnotetext{
${ }^{105}$ Marion's Case at 249 (Mason CJ, Dawson, Toohey and Gaudron JJ) [emphasis added]. ${ }^{106}$ See, generally, Senate Community Affairs References Committee (2013), pp ix-xiv.

${ }^{107}$ Hunter (2006), p 30.

${ }^{108}$ See, for example, Naffine (2009), pp 69, 92-94.

${ }^{109}$ The majority in Marion's Case do acknowledge the significance of the framing of sterilisation in medical terms when they state that 'to characterise intervention comprising sterilisation as "medical treatment" is already to make assumptions and to narrow the inquiry, perhaps inappropriately' because sterilisation 'implies more than medical, or surgical, treatment'. Yet the majority still use terms such as 'procedure' and draw on medical evidence, all of which confirms its medical character: Marion's Case at 232 (Mason CJ, Dawson, Toohey and Gaudron JJ).

${ }^{110}$ See a similar point about the effect of the discourse of medical science in the context of state violence through torture involving medical personnel in Pugliese (2013), p 8.
} 
'non-therapeutic'). ${ }^{111}$ The medical framing of the act of violence of sterilisation intersects with a well-rehearsed narrative of disability as internal lack requiring medical intervention. ${ }^{112}$ Kristin Savell argues that when framed in medical terms, sterilisation constitutes an act of 'rescue' because:

[T] he body represents "disorder" because its reproductive capacities are not contained. Once characterised as disordered in this symbolic sense, attempts to restore order (by removing the threat of pregnancy) can be cast as acts of liberation rather than invasion ... [and] recast as freedom-enhancing. ${ }^{113}$

It follows from the legal characterisation of sterilisation as a medical procedure that the law can then view the subject of a sterilisation-related court application as a medicalised body constituted by his or her biological and psychological processes as opposed to a social and politicised body invested with rights. ${ }^{114}$ Medicalisation also focuses on eliminating, fixing or regulating deviant bodies rather than 'creating a more accessible environment or providing better support services' ${ }^{115}$ or challenging cultural representations of disability as deviancy per se.

This leads to a third limitation with the normal subject of assault which is specifically related to the exception of consent to surgery. The lawfulness of surgery appears value neutral as it is arguable that medical treatment is inherently benevolent and humane. Yet, the lawfulness of acts of violence when characterised as surgery is problematic in the context of abnormal subjects of assault. This is because medicine as an approach has been both a key strategy for rendering people abnormal through diagnosis and a rationale and actual strategy for the use of violence to 'normalise' these individuals. ${ }^{116}$

(3) Familial. The third dimension of the negation of the violence of sterilisation is the characterisation of sterilisation in terms of the family. Court authorised sterilisation is shaped by the nature of the welfare jurisdiction pursuant to which authorisation takes place. This jurisdiction concerns the relations between children and their

${ }^{111}$ Mason CJ, Dawson, Toohey and Gaudron JJ in Marion's Case (at 232) even note 'to characterise intervention comprising sterilisation as "medical treatment" is already to make assumptions and to narrow the inquiry'. They later comment that the question of sterilisation 'has been "medicalised" to a great degree' and that one concern that emerges from this is that 'the decision to sterilise, at least where it is to be carried out for contraceptive purposes, and especially now when technology and expertise make the procedure relatively safe, is not merely a medical issue' and is reflected in concerns raised in some of the cases that 'the consequences of sterilisation are not merely biological but also social and psychological' and involve a possible clash of the interests of the child and 'the independent and possibly conflicting (though legitimate) interests of the parents and other family members': Marion's Case at 251 (Mason CJ, Dawson, Toohey and Gaudron JJ).

${ }^{112}$ Garland-Thomson (2011), pp 22, 26; Goodley and Runswick-Cole (2011), p 603.

${ }^{113}$ Savell (2004), p 1124.

${ }^{114}$ Kafer (2013), pp 8-9; see also Steele (2008); cf Tobin and Luke (2013) the (arguably perverse) argument that involuntary, non-therapeutic sterilisation of girls with intellectual disability can be necessary to realise a girl's human right to health.

${ }^{115}$ Garland-Thomson (2011), p 26, see further p 28; see also Kafer (2013), p 5.

${ }^{116}$ See here the critique of the 'medical model' of disability: Shakespeare (2010); see also Campbell (2009). 
parents and parental responsibilities in relation to their children. ${ }^{117}$ As stated in Marion's Case, constitutionally the welfare jurisdiction is limited in its operation by reference to the constitutional power of marriage and divorce and as such: 'It is clear enough that a question of sterilisation of a child of a marriage arises out of the marriage relationship and that the sterilisation of a child arises from the custody or guardianship of a child'. ${ }^{118}$ Since the High Court's decision on Minister for Immigration and Multicultural and Indigenous Affairs $v B{ }^{119}$ it has been consistently held that the Family Court's jurisdiction to make an order relating to sterilisation is not related to the welfare of the child at large, but is specifically related to a child's welfare in the context of familial relations between parents and children and parental responsibility for the welfare of their children. ${ }^{120}$ It follows from the nature and limits of the jurisdiction that individuals who are the subjects of sterilisation-related applications can only be known within this jurisdiction as children and in terms of their relationship to their parents, including person/s exercising similar custodial relationship. ${ }^{121}$ It is argued that this has the effect of 'freezing time' in terms of that individual's life course, and this easily folds into the construction of people with intellectual disability as 'eternal children', effectively infantilising them. ${ }^{122}$ This freezing of time prevents consideration of future sexual needs and desires of girls with intellectual disability as adults. ${ }^{123}$ This compounds with their abnormal

${ }^{117}$ Steele (2008), pp 11-16.

${ }^{118}$ Marion's Case at 261 (Mason CJ, Dawson, Toohey and Gaudron JJ).

${ }^{119}$ Minister for Immigration and Multicultural and Indigenous Affairs v B (2004) 219 CLR 365. In Minister for Immigration and Multicultural and Indigenous Affairs, the court considered the scope of the welfare power provided by s 67ZC of the Family Law Act 1975 (Cth) in the specific context of Family Court orders sought by the parents of five children held in immigration detention directing the Minister to release these children. The court held that the Family Court does not have jurisdiction under the Family Law Act 1975 (Cth) to make orders against the Minister or other third parties relating to the treatment of the children in immigration detention. For example, Gummow, Hayne and Heydon JJ stated that in its terms, s $69 \mathrm{ZH}$ confines the operation of s $67 \mathrm{ZC}$ to the parental responsibilities of the parties to a marriage for a child of the marriage': Minister for Immigration and Multicultural and Indigenous Affairs v B (2004) 219 CLR 365 at [105], see also [53]-[54], [74], [110], [176]-[177], [204], [207]. In their reasons for judgment concluded that the Family Court's welfare jurisdiction was limited by s $67 \mathrm{ZH}$ which 'confines the operation of s $67 \mathrm{ZC}$ to the parental responsibilities of the parties to a marriage for a child of the marriage': Minister for Immigration and Multicultural and Indigenous Affairs v B (2004) 219 CLR 365 at [74]. In their reasons for judgment, Gleeson CJ and McHugh $\mathbf{J}$ were of the view that the Family Court's welfare jurisdiction was not at large, and did not extend to the making of orders binding on third parties even when it would advance the welfare of the child to do so: Minister for Immigration and Multicultural and Indigenous Affairs v B (2004) 219 CLR 365 at [28], [50]-[54].

${ }^{120}$ Re Baby D (No 2) (2011) 258 FLR 290 at [193]; see also Re Alex (2009) 298 FLR 312 at [121], [113]-[130]; Re Sean and Russell (Special Medical Procedures) (2010) 258 FLR 192 at [66]-[75]; Re Inaya (Special Medical Procedure) (2007) 213 FLR 278 at [48]-[53]; Re Bernadette (2011) 249 FLR 294 at [55], see also [45]-[54].

${ }^{121}$ Steele (2008), pp 11-16.

${ }^{122}$ Steele (2008), pp 11-14.

${ }^{123}$ Keywood (2001), p 192; see also Keywood (1995); Goodley and Runswick-Cole (2013). 
sexuality as children, ${ }^{124}$ and results in the "positioning of [individuals] beyond the realm of sexed legal subjectivity ${ }^{125}$ and instead they are positioned in terms of a 'desperately crude, medicalised picture of human bodies'. ${ }^{126}$

It also follows from the scope and limits of the Family Court's welfare jurisdiction that orders made pursuant to s $67 \mathrm{ZC}$ are limited to the parent/child relationship rather than their welfare at large. ${ }^{127}$ It follows from this decision that the Family Court does not have jurisdiction to order the state to provide disability support services, respite care, or financial assistance to families, or to engage in broader systemic changes around discrimination against people with disability. ${ }^{128}$ This depoliticises, privatises and individualises the circumstances giving rise to the sterilisation application and it legitimises a legal outcome focused on medical intervention and violence on a child's body as opposed to resource allocation to families or systemic change to the economic, social and political status of people with disability in society. ${ }^{129}$ This tracks onto the pathologising of the individual in terms of her disability. ${ }^{130}$ Thus, the welfare jurisdiction makes sterilisation a private family issue as opposed to a systemic and political issue, an obligation of parental care for their child as opposed to an obligation of the state to provide support and resources, and hence the child's body becomes the appropriate target of (a violent) intervention as opposed to society being identified as the target of systemic change.

The familial character of the violence of court authorised sterilisation is strikingly at odds with the focus in the welfare jurisdiction on the prevention of family violence and child abuse. One of the purposes of Part VII of the Family Law Act 1975 (Cth) and the 'best interests' test is to protect children from family violence. The best interests test, which must be the "paramount consideration" 131 when the court decides whether to make an order pursuant to s $67 \mathrm{ZC}$, including one relating to sterilisation under $\mathrm{s} 67 \mathrm{ZC},{ }^{132}$ is premised on protecting children from abuse and family violence. ${ }^{133}$ Additionally, s $60 \mathrm{CG}$ provides that in considering what order to make, the court must, to the extent that it is possible to do so consistently with the child's best interests being the paramount consideration, ensure that the order ... does not expose a person to an unacceptable risk of family violence'. ${ }^{134}$ On the one hand, in the Family Court's welfare jurisdiction, sterilisation in the context of the

\footnotetext{
${ }^{124}$ Keywood (2002), pp 29-30; see also point made by Kafer (2013, p 65) in the context of the US case of 'Ashley X'.

${ }^{125}$ Keywood (2001), p 192.

${ }^{126}$ Keywood (2001), p 193.

${ }^{127}$ Minister for Immigration and Multicultural and Indigenous Affairs v B (2004) 219 CLR 365, at [28], [52] (Gleeson CJ and McHugh J), see further [53]. See also Secretary, Department of Health and Human Services v Ray (2010) 45 Fam LR 1 at [88]-[90].

${ }^{128}$ Steele (2008), pp 14-15; see similar point made by Kafer (2013, pp 60-62) in the context of the US case of 'Ashley X'.

${ }^{129}$ Steele (2008), pp 14-16, 21-23, 33; see also Keywood (1995), pp 125, 135-138.

${ }^{130}$ Keywood (1995), pp 125, 130.

${ }^{131}$ Family Law Act 1975 (Cth) s 60CA.

${ }^{132}$ Re Baby D (No 2) (2011) 258 FLR 290 at [171].

${ }^{133}$ Family Law Act 1975 (Cth) s 60B(1)(b).

${ }^{134}$ Family Law Act 1975 (Cth) s 60CG(1)(b).
} 
parent-child relationship is said to be in the best interests of a child with disability yet, on the other hand, the welfare jurisdiction is supposed to protect children from family violence and abuse, and sterilisation is a form of violence. As such, the current jurisdictional framework results in a contradictory situation where the Family Court can authorise an act of family violence (in the form of sterilisation of a child with disability) pursuant to a test that has as part of its purported purpose the protection of children from family violence. The Family Court's 'supervisory' jurisdiction over parents vis-à-vis non-therapeutic sterilisation means it not only fails to protect children from family violence, but actually permits and legitimises a form of family violence that, by the contours of its very jurisdiction, it should in fact be protecting children from. ${ }^{135}$ Moreover, whereas the factors in the Family Law Act 1975 (Cth) apply to all decisions under s 67ZC, the Family Court's decision in Re Marion (No 2) ${ }^{136}$ provided considerations specifically in relation to when a sterilisation would be in the best interests of a child. These are focused on treatment and hence re-frame sterilisation in terms of benevolent treatment and individual pathology rather than the family violence that is in the legislation. Thus, in a context where there is an increasing public and policy awareness and action on domestic and family violence, sterilisation continues to be supported as a lawful form of violence, even in a legal framework that has as its paramount consideration the prevention of violence. This shows in the context of sterilisation just how pervasive the division is between 'good' violence of the law, and 'bad violence' external to the law.

\section{Towards recognition of sterilisation as violence: disability, violence and criminal law}

This article has explored the intersections of the criminal law of assault and the Family Court's welfare jurisdiction in the legal framing of court authorised sterilisation of girls with intellectual disability as a legally permissible form of violence. Through drawing on the concepts of 'legal violence' and 'abnormality', the article demonstrated the complex and central role of law in the violence done to girls with intellectual disability through sterilisation. The article argued that court authorised sterilisation of girls with intellectual disability is a form of lawful and 'good' violence against abnormal legal subjects. While authorisation of sterilisation occurs in the Family Court's welfare jurisdiction, it is the criminal law of assault which provides the contours of unlawful violence and hence the necessity for this court authorisation. The criminal law of assault provides the possibility for violence of surgery to be lawful when consented to. While typically this consent is given by the subject of the surgery, girls with intellectual disability by reason of their incapacity are positioned outside the normal legal subject of assault who has the capacity to decide to consent to contact with his or her otherwise impermeable body. As girls with intellectual disability are 'abnormal' legal subjects of assault, the lawfulness of the contact involved in the act of their sterilisation is not dependent on their consent, but instead on the consent of their parents as authorised by the Family

\footnotetext{
${ }^{135}$ From a slightly different angle, see Brennan J's dissenting comments concerning the relationship between the welfare jurisdiction and involuntary non-therapeutic sterilisation as criminal conduct: Marion's Case at 284-285 (Brennan J).

${ }^{136}$ In Re Marion (No 2) (1992) 17 Fam LR 336.
} 
Court acting in its welfare jurisdiction. In the course of authorising parental consent to sterilisation, the Family Court not only renders an act of sterilisation lawful violence, but also 'good' violence through the characterisation of girls with intellectual disability as absolutely different to individuals without disability and through the characterisation of the act of sterilisation in legal, familial and medical terms. Through constructing sterilisation as 'good' violence, law legitimates its actions of violence because the construction of legal violence as humane and beneficial masks its negative character.

There are three key implications of this article's argument about the role of the criminal law of assault in the legal framing of sterilisation as a legally permissible form of violence against girls with intellectual disability. The first implication is that the article highlights the importance of any scholarship or advocacy on sterilisation, particularly that which argues for the prohibition of sterilisation through criminalisation, engaging with criminal law's implication in this violence. This is particularly pressing in the current law reform landscape following the recent recommendations of the Senate Community Affairs Reference Committee which focus on strengthening the framework for court authorised sterilisation, accompanied by criminalising unauthorised procedures. ${ }^{137}$ Engagement with the issue of criminalisation of sterilisation might also contemplate the violence done against people with disability through criminalisation more broadly. ${ }^{138}$ Discussing the criminalisation of hate speech against transgender people, Dean Spade reflects on the broader context of state violence done through the criminal justice system against transgender people. Spade queries whether seeking the assistance of criminal law will simply exacerbate and strengthen the very systems of criminal law and criminal justice that repress transgender people who come into contact with criminal law and the criminal justice system as offenders. ${ }^{139}$ A similar argument might be made in relation to the criminalisation of sterilisation, given that people with disability are over-represented in the criminal justice system as offenders and are discriminated against, and vulnerable to violence, in prison, ${ }^{140}$ as well as the fact that prison itself is a disabling environment. $^{141}$

The second implication is that there needs to be greater scholarship on the relationships between disability, violence and law. Noting the existing absence of scholarship on disability and legal violence, this article has highlighted the significance of norms of ability (and their intersection with norms of gender and sexuality) to the legal ordering of violence. These findings suggest the need for consideration of the centrality of disability to legal violence, as well as the specific relationship between disability and foundational legal concepts of consent, capacity and bodily inviolability, and broader ideas of autonomy, rationality and capacity that underpin law's positioning of girls with intellectual disability outside of full

\footnotetext{
${ }^{137}$ See, generally, Senate Community Affairs References Committee (2013), pp ix-xiv.

${ }^{138}$ See also Hunter (2006), pp 45-46.

${ }^{139}$ Spade $(2011,2012)$; see also (in the context of females and homosexual males) Hunter (2006), pp 44-46.

${ }^{140}$ See, for example, Baldry et al (2012); New South Wales Law Reform Commission (2012); Australian Human Rights Commission $(2013,2014)$.

${ }^{141}$ See, for example, Ribet (2010).
} 
humanness and (insofar as assault contributes to the ordering of human relations) outside of full community. ${ }^{142}$ These considerations are not only relevant to sterilisation but to the number of other forms of legally permissible violence specific to people with disability. Examples of these forms of violence include forced psychiatric treatment, civil commitment, behavioural interventions and physical restraint. Further examples include the ways in which the state "withhold[s] the force of law and shar[es] the use of force ${ }^{143}$ with those who use violence against people with disability through legal defences that enable the greater permissibility of killing people with disability and evidence laws that can prevent individuals with disability from being witnesses in sexual assault matters. ${ }^{144}$ In a context where 'the relation of the person to her or his own embodied personhood' is 'the primary ground' of all civil rights, ${ }^{145}$ challenging the relationships between disability, body, mind and law will have wide ramifications for the legal and political status of people with disability, extending beyond their experiences of specific acts of physical force to their broader place in human relationships and social and civil communities. ${ }^{146}$

The third implication is that the article provides new directions for critical legal and feminist legal scholarship on the role of law in violence against other groups of individuals. In the specific context of violence at the intersections of criminal law and family law, the article is relevant to analyses of the court authorisation of medical procedures on transgender children. ${ }^{147}$ In particular, the article's illumination of the important intersections of norms of gender, sexuality and disability can be useful in analysing the place of diagnoses of 'gender dysphoria' and 'gender identity disorder' in the legal construction of 'transgender' children and in the legal regulation of medical treatment related to these diagnoses. More broadly, in a context where there is a mutually constitutive relationship between normality/ability and abnormality/ disability, this article has demonstrated that the margins of the disabled sterilised subject help to construct the centre of the normal subject of violence ${ }^{148}$ and hence to reinforce norms of ability, gender and sexuality which non-disabled individuals must conform to in order to benefit from the law's protection against unlawful violence afforded to 'normal' legal subjects. This could have broader ramifications to other areas of law, such as consent and choice in contract law and reasonableness in tort law. Moreover, in light of the inter-articulation of norms of ability, gender and sexuality in the legal regulation of violence discussed above, the article also provides

\footnotetext{
${ }^{142}$ See, generally, Carey (2009), p 17.

${ }^{143}$ Hunter (2006), p 32 (in the context of violence against female and gay male bodies); see also Wald (1995), pp 92-96. In the context of the role of criminal law in sanctioning violence against homosexual males, see Thomas (1992); Golder (2012); in the context of law's sanctioning of violence against females and homosexual males, see Hunter (2006).

${ }^{144}$ See, for example, the issues facing people with disability who are victims of sexual assault: Keilty and Connelly (2001); Murray and Powell (2008); Murray and Heenan (2012).

${ }^{145}$ Scarry (1990), p 869, see generally pp 869-870.

${ }^{146}$ Kittay (2011). This article's analysis of sterilisation might also provide new openings into the use of Foucault's governmentality analysis vis-à-vis disability, abnormality and criminal law; see, for example, Golder (2012) in the context of governmentality, criminal law and homosexuality.

${ }^{147}$ See, generally, Bell (2015).

${ }^{148}$ Garland-Thomson (2011), p 18.
} 
new openings for analyses of legal violence against and construction of legal subjectivity of other groups cast as 'abnormal' or 'other' on the basis of gender, sexuality or race. ${ }^{149}$ This is particularly relevant to those critical legal scholars and critical legal feminist scholarship whose current critiques of the legal construction of gender, sexuality and race ignore and implicitly naturalise disability. ${ }^{150}$ Ultimately, until the norms on which the abnormal legal subject of violence is produced are challenged, law will continue to permit violence against girls with intellectual disability, the body of the sterilised girl with intellectual disability will continue to be a site where norms of ability, gender and sexuality are reinforced, ${ }^{151}$ and the legally (and socially and politically) privileged 'normal' body will continue to be produced through legal violence against girls with intellectual disability. ${ }^{152}$

\section{Acknowledgements}

This article draws on a submission made to the 2012-2013 Senate Community Affairs References Committee Inquiry into the Involuntary or Coerced Sterilisation of People With Disabilities in Australia. Thanks to Nan Seuffert and Elaine Newby for their comments on earlier drafts and to the anonymous reviewers for their helpful feedback.

\section{References \\ Primary sources}

Cases

Attorney-General's Reference (No 6 of 1980) [1981] QB 715

Boughey v R (1986) 161 CLR 10

Collins v Wilcock [1984] 3 All ER 374

DPP v Smith [1961] AC 290

Fagan v Metropolitan Police Commissioner [1969] 1 QB 439

Minister for Immigration and Multicultural and Indigenous Affairs v B (2004) 219 CLR 365

$R v$ Billinghurst [1978] Crim LR 553

$R v$ Brown [1994] 1 AC 212

$R v$ Coney (1882) 8 QBD 534

$R v$ Donovan [1934] 2 KB 498

$R v$ Emmett (unreported, [1999] EWCA Crim 1710 (18 June 1999)

$R v$ Wilson [1996] 3 WLR 125

Re Alex (2009) 298 FLR 312

Re Baby D (No 2) (2011) 258 FLR 290

Re Bernadette (2011) 249 FLR 294

Re Inaya (Special Medical Procedure) (2007) 213 FLR 278

Re Marion (No 2) (1992) 17 Fam LR 336

Re P (1995) 126 FLR 245

Re Sean and Russell (Special Medical Procedures) (2010) 258 FLR 192

Schloendorff $v$ Society of New York Hospital (1914) 105 NE 92

Secretary, Department of Health and Community Services v JWB (1992) 175 CLR 218 (Marion's Case)

Secretary, Department of Health and Human Services v Ray (2010) 45 Fam LR 1

\footnotetext{
${ }^{149}$ Garland-Thomson (2011), pp 16-17.

${ }^{150}$ On feminism and ableism, see Lamp and Cleigh (2011), pp 175, 187.

${ }^{151}$ Keywood (2002), p 31; Savell (2004), p 1096.

${ }^{152}$ Goodley and Runswick-Cole (2011), p 612.
} 
Legislation

Crimes Act 1900 (NSW)

Family Law Act 1975 (Cth)

\section{Secondary sources}

Anthony V Alfieri (1994) 'Book Review: The Ethics of Violence: Necessity, Excess, and Opposition: Law's Violence. Edited by Austin Sarat and Thomas R Kearns' 94 Columbia Law Review 1721.

Barry Allen (2005) 'Foucault's Nominalisation' in S Tremain (ed), Foucault and the Government of Disability, University of Michigan Press.

Australian Human Rights Commission (2012) The Involuntary or Coerced Sterilisation of People With Disabilities in Australia: Australian Human Rights Commission Submission to the Senate Community Affairs References Committee, Australian Human Rights Commission.

Australian Human Rights Commission (2013) Access to Justice in the Criminal Justice System for People With Disability: Issues Paper, Australian Human Rights Commission.

Australian Human Rights Commission (2014) Equal Before the Law: Towards Disability Justice Strategies, Australian Human Rights Commission.

Eileen Baldry et al (2012) People With Intellectual and Other Cognitive Disability in the Criminal Justice System, Family and Community Services: Ageing, Disability and Home Care.

Felicity Bell (2015) 'Children With Gender Dysphoria and the Jurisdiction of the Family Court' 38 UNSW Law Journal (forthcoming).

Lois Bibbings (2000) 'Boys Will Be Boys: Masculinity and Offences Against the Person' in D Nicolson and L Bibbings (eds) Feminist Perspectives on Criminal Law, Cavendish Publishing Limited.

Susan Brady et al (2001) The Sterilisation of Girls and Young Women in Australia: Issues and Progress, Australian Human Rights Commission.

Elizabeth Broderick (2012) 'Violence Against Women With a Disability in Rural Australia', paper presented at the Rural Women and Girls With Disabilities: Economic Empowerment and Political Participation, United Nations Headquarters, New York, http://humanrights. gov.au/about/media/speeches/sex_discrim/2012/20120322_csw_disability.html.

Jo Bridgeman (1995) 'Declared Innocent?' 3 Medical Law Review 117.

Simon Bronitt and Bernadette McSherry (2010) Principles of Criminal Law 3rd edn, Lawbook Co.

Fiona Kumari Campbell (2009) Contours of Ableism: The Production of Disability and Abledness, Palgrave Macmillan.

Alison C Carey (2009) On the Margins of Citizenship: Intellectual Disability and Civil Rights in Twentieth-Century America, Temple University Press.

Mairian Corker and Sally French (1999) 'Reclaiming Discourse in Disability Studies' in M Corker and S French (eds) Disability Discourse, Open University Press.

Mairian Corker and Tom Shakespeare (2002) 'Mapping the Terrain' in M Corker and T Shakespeare (eds) Disability/Postmodernity: Embodying Disability Theory, Continuum.

Robert Cover (1986) 'Violence and the Word' 95 The Yale Law Journal 1601.

Michael Desjardins (2012) 'The Sexualised Body of the Child: Parents and the Politics of "Voluntary" Sterilization of People Labeled Intellectually Disabled' in R McRuer and A Mollow (eds) Sex and Disability, Duke University Press.

Leanne Dowse et al (2013) Stop the Violence: Discussion Paper, Women With Disabilites Australia.

Phillip French et al (2009) Rights Denied: Towards a National Policy Agenda About Abuse, Neglect and Exploitation of Persons With Cognitive Impairment, People With Disability Australia.

Carolyn Frohmader (2012) Moving Forward and Gaining Ground: The Sterilisation of Women and Girls With Disabilities in Australia, Women With Disabilities Australia.

Carolyn Frohmader (2013) Dehumanised: The Forced Sterilisation of Women and Girls With Disabilities in Australia, Women With Disabilities Australia. 
Rosemarie Garland-Thomson (2011) 'Integrating Disability, Transforming Feminist Theory' in KQ Hall (ed) Feminist Disability Studies, Indiana University Press.

Ben Golder (2004) "'It Forced Me to Open More Than I Could Bear": H.A.D., Paedophilia, and the Discursive Limits of the Male Heterosexual Body' in AT Kenyon and P Rush (eds) An Aesthetics of Law and Culture: Texts, Images, Screens, Elsevier.

Ben Golder (2012) 'The Distribution of Death: Notes Towards a Bio-Political Theory of Criminal Law' in M Stone et al (eds) New Critical Legal Thinking: Law and the Political, Birkbeck Law Press.

Dan Goodley and Katherine Runswick-Cole (2011) 'The Violence of Disablism' 33 Sociology of Health and Illness 602.

Dan Goodley and Katherine Runswick-Cole (2013) 'The Body as Disability and Possibility: Theorising the "Leaking, Lacking and Excessive" Bodies of Disabled Children' 15 Scandinavian Journal of Disability Research 1.

Kim Q Hall (2011) 'Reimagining Disability and Gender Through Feminist Disability Studies' in KQ Hall (ed) Feminist Disability Studies, Indiana University Press.

Karen Hughes et al (2012) 'Prevalence and Risk of Violence Against Adults With Disabilities: A Systematic Review and Meta-Analysis of Observational Studies' 379(9826) Lancet 1621.

Rosemary Hunter (2006) 'Law's (Masculine) Violence: Reshaping Jurisprudence' 17 Law and Critique 27.

Michelle Jarman (2012) 'Dismembering the Lynch Mob: Intersecting Narratives of Disability, Race and Sexual Menace' in R McRuer and A Mollow (eds) Sex and Disability, Duke University Press.

Alison Kafer (2013) Feminist, Queer, Crip, Indiana University Press.

Jennifer Keilty and Georgina Connelly (2001) 'Making a Statement: An Exploratory Study of Barriers Facing Women With an Intellectual Disability When Making a Statement About Sexual Assault to Police' 16 Disability and Society 273.

Kirsty Keywood (1995) 'Sterilising the Woman With Learning Difficulties - In Her Best Interests?' in J Bridgeman and S Millns (eds) Law and Body Politics: Regulating the Female Body, Dartmouth.

Kirsty Keywood (2001) "I'd Rather Keep Him Chaste": Retelling the Story of Sterilisation, Learning Disability and (Non)Sexed Embodiment' 9 Feminist Legal Studies 185.

Kirsty Keywood (2002) 'Disabling Sex: Some Legal Thinking About Sterilization, Learning Disability and Embodiment' in AE Morris and SM Nott (eds) Well Women: The Gendered Nature of Health Care Provision, Ashgate Publishing.

Eva Feder Kittay (2011) 'Forever Small: The Strange Case of Ashley X' 26 Hypatia 610.

Nicola Lacey (1997) 'On the Subject of "Sexing" the Subject ...' in N Naffine and RJ Owens (eds) Sexing the Subject of Law, LBC Information Services.

Nicola Lacey (1998) 'Unspeakable Subjects, Impossible Rights: Sexuality, Integrity and Criminal Law' XI Canadian Journal of Law and Jurisprudence 47.

Nicola Lacey (2000) 'General Principles on Criminal Law? A Feminist View' in D Nicolson and L Bibbings (eds) Feminist Perspectives on Criminal Law, Cavendish Publishing Limited.

Sharon Lamp and W Carol Cleigh (2011) 'A Heritage of Ableist Rhetoric in American Feminism from the Eugenics Period' in KQ Hall (ed) Feminist Disability Studies, Indiana University Press.

Robert McRuer and Anna Mollow (2012) 'Introduction' in R McRuer and A Mollow (eds) Sex and Disability, Duke University Press.

Juan E Méndez (2013) Report of the Special Rapporteur on Torture and Other Cruel, Inhuman or Degrading Treatment or Punishment, United Nations, Human Rights Council 22nd session, agenda item 3, UN Doc A/HRC/22/53.

Leslie J Moran (1995) 'Violence and the Law: The Case of Sado-Masochism' 4 Social and Legal Studies 225.

Suellen Murray and Melanie Heenan (2012) 'Reported Rapes in Victoria: Police Responses to Victims With a Psychiatric Disability or Mental Health Issue' 23 Current Issues in Criminal Justice 353.

Suellen Murray and Anastasia Powell (2008) Sexual Assault and Adults With a Disability: Enabling Recognition, Disclosure and a Just Response, Australian Centre for the Study of Sexual Assault. 
Ngaire Naffine (1997) 'The Body Bag' in N Naffine and RJ Owens (eds) Sexing the Subject of Law, LBC Information Services.

Ngaire Naffine (2009) Law's Meaning of Life: Philosophy, Religion, Darwin and the Legal Person, Hart Publishing.

Jennifer Nedelsky (1989) 'Reconceiving Autonomy: Sources, Thoughts and Possibilities' 1 Yale Journal of Law and Feminism 7.

Jennifer Nedelsky (1990) 'Laws, Boundaries and the Bounded Self' 30 Representations 162.

Nick O'Neill and Carmelle Peisah (2011) Capacity and the Law, Sydney University Press.

New South Wales Law Reform Commission (2012) People With Cognitive and Mental Health Impairments in the Criminal Justice System: Diversion, report no. 135, New South Wales Law Reform Commission.

Liz Olle (2006) Violence-Induced Disability: The Consequences of Violence Against Women and Children, Domestic Violence and Incest Resource Centre.

Joseph Pugliese (2013) State Violence and the Execution of Law: Biopolitical Caesurae, Torture, Black Sites, Drones, Routledge.

Beth Ribet (2010) 'Naming Prison Rape as Disablement: A Critical Analysis of the Prison Litigation Reform Act, the Americans With Disabilities Act, and the Imperatives of Survivor-Oriented Advocacy' 17 Virginia Journal of Social Policy and the Law 281.

Matthew Rollinson (2000) 'Re-Reading Criminal Law: Gendering the Mental Element' in D Nicolson and L Bibbings (eds) Feminist Perspectives on Criminal Law, Cavendish Publishing Limited.

Alan Roulstone and Hannah Mason-Bish (eds) (2013) Disability, Hate Crime and Violence, Routledge.

Austin Sarat (2001) 'Situating Law Between the Realities of Violence and the Claims of Justice' in A Sarat (ed) Law, Violence, and the Possibility of Justice, Princeton University Press.

Austin Sarat and Thomas R Kearns (1992) 'Introduction' in A Sarat and TR Kearns (eds) Law's Violence, University of Michigan Press.

Kristin Savell (2004) 'Sex and the Sacred: Sterilization and Bodily Integrity in English and Canadian Law' 49 McGill Law Journal 1094.

Elaine Scarry (1990) 'Consent and the Body: Injury, Departure, and Desire' 21 New Literary History 867.

Senate Community Affairs References Committee (2013) Involuntary or Coerced Sterilisation of People with Disabilities in Australia, Senate Community Affairs Committee Secretariat.

Tom Shakespeare (2010) 'The Social Model of Disability' in LJ Davis (ed) The Disability Studies Reader, Routledge.

Margrit Shildrick (1997) Leaky Bodies and Boundaries: Feminism, Postmodernism and (Bio) ethics, Routledge.

Margrit Shildrick (2002) Embodying the Monster: Encounters With the Vulnerable Self, Sage Publications.

Margrit Shildrick (2009) Dangerous Discourses of Disability, Subjectivity and Sexuality, Palgrave Macmillan.

Andrew Simester et al (2010) Simester and Sullivan's Criminal Law: Theory and Doctrine, Hart Publishing.

Dean Spade (2011) Normal Life: Administrative Violence, Critical Trans Politics, and the Limits of Law, South End Press.

Dean Spade (2012) 'Their Laws Will Never Make Us Safer' in R Conrad (ed) Against Equality: Prisons Will Not Protect You, AK Press.

Linda Steele (2008) 'Making Sense of the Family Court's Decisions on the Non-Therapeutic Sterilisation of Girls With Intellectual Disability' 22 Australian Journal of Family Law 1.

Linda Steele (2013) Submission No 44 to the Senate Community Affairs References Committee, Inquiry into the Involuntary or Coerced Sterilisation of People With Disabilities in Australia.

Kendall Thomas (2005) 'Imagining Lesbian Legal Theory' 8 New York City Law Review 505.

John Tobin and Elliot Luke (2013) 'The Involuntary, Non-Therapeutic Sterilisation of Women and Girls With an Intellectual Disability - Can it Ever Be Justified?' 3 Victoria University Law and Justice Journal 27. 
Shelley Tremain (2002) 'On the Subject of Impairment' in M Corker and T Shakespeare (eds) Disability/Postmodernity: Embodying Disability Theory, Continuum.

Shelley Tremain (2005) 'Foucault, Governmentality, and Critical Disability Theory: An Introduction' in S Tremain (ed) Foucault and the Government of Disability, University of Michigan Press.

Patricia M Wald (1995) 'Violence Under the Law: A Judge's Perspective' in A Sarat and TR Kearns (eds) Law's Violence, University of Michigan Press.

Celia Wells and Oliver Quick (2010) Lacey, Wells and Quick: Reconstructing Criminal Law: Text and Materials, Cambridge University Press.

Women With Disability Australia et al (2011) Sterilisation of Women and Girls with Disabilities: A Briefing Paper, Global Campaign to Stop Torture in Health Care. 